\title{
Genetic analysis of milking ability in Lacaune dairy ewes
}

\author{
Christel MARIE-ETANCELIN*, Eduardo MANFREDI, \\ Marie-Rose AUREL, François PAILlER, Jean ARHAINX, \\ Edmond RICARD, Gilles LAGRIFFOUL, Philippe GuILlOUET, \\ Bernard BIBÉ, Francis BARILLET
}

Station d'amélioration génétique des animaux, Institut national de la recherche agronomique, BP 52 627, 31326 Castanet-Tolosan Cedex, France

(Received 2 May 2005; accepted 21 October 2005)

\begin{abstract}
The milking ability of Lacaune ewes was characterised by derived traits of milk flow patterns, in an INRA experimental farm, from a divergent selection experiment in order to estimate the correlated effects of selection for protein and fat yields. The analysis of selected divergent line effects (involving 34616 data and 1204 ewes) indicated an indirect improvement of milking traits $(+17 \%$ for maximum milk flow and $-10 \%$ for latency time) with a $25 \%$ increase in milk yield. Genetic parameters were estimated by multi-trait analysis with an animal model, on 751 primiparous ewes. The heritabilities of the traits expressed on an annual basis were high, especially for maximum flow (0.54) and for latency time (0.55). The heritabilities were intermediate for average flow (0.30), time at maximum flow (0.42) and phase of increasing flow (0.43), and low for the phase of decreasing flow (0.16) and the plateau of high flow (0.07). When considering test-day data, the heritabilities of maximum flow and latency time remained intermediate and stable throughout the lactation. Genetic correlations between milk yield and milking traits were all favourable, but latency time was less milk yield dependent $(-0.22)$ than maximum flow $(+0.46)$. It is concluded that the current dairy ewe selection based on milk solid yield is not antagonistic to milking ability.
\end{abstract}

dairy sheep / milk flow / milking ability / milking trait / divergent selection

\section{INTRODUCTION}

Current selection in the Lacaune dairy sheep is based on a global criterion of dairy selection "fat and protein yields in milk". Since 1993, the selection scheme has yielded substantial genetic gains in milk quantity and milk composition [1]. At present, Lacaune breeders wish to include new criteria, in particular functional traits, in the selection programme. Due to the evolution of

*Corresponding author: marie@ toulouse.inra.fr 
techniques and equipment for milking (increasing size of milking facilities, the use of automatic unhooking associated with a higher ratio "number of ewes/milker"), milking ease of an animal has become a key factor of labour efficiency. The success of each step of milking requires an optimal milking speed and the calm behaviour of the animals in the milking parlour. Also, the improvement of milking ability must not adversely affect udder health, and in particular, susceptibility to mastitis. In the 1970s, scientists from Mediterranean countries worked on the physiology of milk emission in the ewe $[9,13]$; however, the estimates of genetic parameters of milking ability are lacking.

The objective of this work was (i) to verify the impact of dairy selection on the milking ability of ewes under mechanised milking conditions, and (ii) to analyse the genetic relationships between several components of milking traits and milk yield. The study was carried out at the INRA experimental station of La Fage, where milking ability has been automatically recorded since 1996.

\section{MATERIALS AND METHODS}

\subsection{Flock studied}

The experimental sheep flock of INRA La Fage consists of 550 Lacaune lactating females, reared under a system similar to that usually found on commercial farms. A divergent selection on fat and protein yields has been practiced since 1989: High and Low lines (HL and LL respectively) were selected according to the official Lacaune index during six generations from 1989 to 2001. Selection was performed on the male side: about 10 top-ranked rams and 10 bottom-ranked rams having been chosen annually among 700 artificial insemination rams of the Lacaune dairy breeding programme [3] to produce 4-5 daughters per sire at the INRA experimental flock. As far as possible, sires were sampled randomly within lines. Since 1995, all ewes belong to the divergent third generations and more: the attained divergence in milk yield has remained constant, about $61 \mathrm{~L}$ (2 genetic standard deviations), while the estimated breeding values remained similar for fat and protein contents in both lines [2]. In this article, we compared milking traits of both lines in order to evaluate the indirect influence of milk selection on milking ability.

\subsection{Tools for milking ability measurements}

The tool for milking ability recording was an automatic milk-recording device, conceived by the INRA-SAGA (European patent No. 94916284.6) 
according to the precision standards of ICAR (International Committee of Animal Recording) [20]. This machine consists of a set of 24 jars controlled by a central processor, which allows recording, at each milking, of the intermediate yields as well as the total quantity of milk produced. The individual measures for every jar, obtained during the collective milking, corresponded to the following:

- total yield at milking (YT);

- 12 intermediate measurements of milk yield every $10 \mathrm{~s}$ after the first milk measurement;

- the estimated latency time (TL): the time between the cluster attachment and the arrival of $160 \mathrm{~mL}$ of milk in the jar (needed to obtain a first measurement of milk). Strictly speaking, TL should measure the time of suction necessary to extract the first drop of milk. The measurements presented here are an overestimation of the strict latency time, because they included the additional time necessary to obtain a minimum measurable quantity of milk in the jar. This extra time was estimated as $15 \mathrm{~s}$ at INRA La Fage, during the testing period of the milk-recording tool.

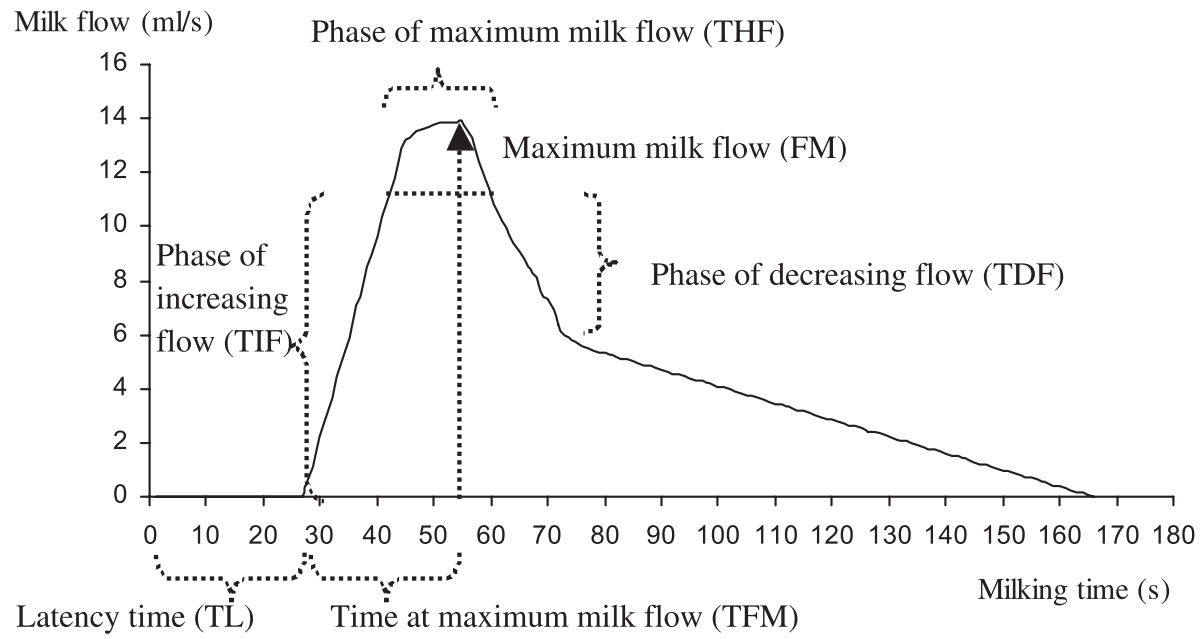

Figure 1. Schematic milk flow pattern.

The measurements were used to compute derived variables representing milk flow patterns (Fig. 1):

- the average of the 11 calculated flows (FA) from the 12 intermediate measurements of milk quantity; 
- the maximum milk flow (FM), i.e. the maximum of the 11 calculated flows;

- the time at maximum milk flow (TFM; computed from the latency time);

- the duration of the phase of maximum milk flow (THF) determined as the time when milk flow was at least $80 \%$ of the maximum milk flow;

- the duration of the phase of increasing flow (TIF), previous to the maximum flow, and determined as the time when flows increased from $0 \%$ to $80 \%$ of the maximum milk flow;

- the duration of the phase of decreasing flow (TDF), after the maximum flow, and determined as the time when flows decreased from $80 \%$ to $40 \%$ of the maximum milk flow.

The milking system of La Fage is a high pipeline system in a parallel parlour with 48 places and 24 clusters, with a $36 \mathrm{kPa}$ vacuum, a milk-rest ratio of $50 / 50$, and a pulsation rate of 174/min. Two milkers are able to milk 550 ewes in 1.5 to $2.5 \mathrm{~h}$, depending on lactation stage.

\subsection{Data}

The data included 34616 milking records collected from 1997 to 2001, corresponding to 1204 ewes sired by 299 AI rams, giving an average of 4 ewes per ram (3.5 ewes per ram for 117 Low Line rams and 4.3 ewes per ram for 182 High Line rams). Repeated data arise from three sources: the ewes were recorded up to 9 times per lactation (9 annual official test-day records (TD 1 to 9) with a recording interval of 3 weeks), at morning and evening milkings, and at parities varying from 1 to 5 .

Three data sets were studied (Tab. I). Data set A included all data and it was used for phenotypic analysis, in particular to test the effects of divergent lines on milking traits. Data set B, a subset of A, included all data of morning milkings of primiparous ewes. It was used to study genetic parameters in a multi-trait analysis between test-days. Data set C, a summary of data set B, included average data per ewe and per lactation, when the ewes have at least 4 test day records per year. It was used for the estimation of genetic parameters of annual average records in primiparous ewes. In order to estimate genetic parameters using files $\mathrm{B}$ and $\mathrm{C}$, the pedigree data included 3975 records obtained by tracing back five generations of ancestors (on male and female sides) of 751 primiparous ewes measured in the study.

Whatever the data set, the studied traits were milk yield (YT), latency time (TL), milk flows (FA, FM) and time variables (TFM, TIF, THF, TDF) describing the flow pattern. 
Table I. Description of the three data sets.

\begin{tabular}{lccc}
\hline Data set & A & B & C \\
\hline N of records & 34616 & 4455 & 751 \\
N of ewes & 1204 & 751 & 751 \\
Milking & Morning and evening & Morning only & Morning only \\
Parity & 1 to 5 & 1 & 1 \\
Phenotypes & Elementary records & Elementary records & Annual average records \\
Purpose & Phenotypic analysis & Genetic parameters & Genetic parameters \\
\hline
\end{tabular}

\subsection{Statistical analysis}

\subsubsection{Data transformation}

In order to normalise the data, a logarithmic transformation was applied to the traits related to time that presented a very asymmetrical distribution: latency time (TL) and time at maximum milk flow (TFM). Transformed latency time was $\log (\mathrm{TL}+4)$ and transformed time at maximum milk flow was log (TFM). These transformations gave the best coefficients of kurtosis and skewness. However, the variables corresponding to the three phases of milk flow (TIF, THF and TDF) could not be well normalised by a logarithmic transformation; thus, the tests of fixed effects for these skewed distributions are to be considered with caution.

\subsubsection{Effects of milk yield selection on milking ability}

File A was used to test the effects of several variation factors on milking traits, in particular the effects of divergent selected lines. Also, phenotypic correlations among milking traits and milk yield were estimated. Computations were performed with proc Mixed of SAS ${ }^{\circledR}[23]$.

The model included six fixed effects:

$$
\mathrm{Y}_{\mathrm{ijklmnpqr}}=\mathrm{D}_{\mathrm{i}}+\mathrm{L}_{\mathrm{j}}+\mathrm{T}_{\mathrm{k}}+\mathrm{P}_{1}+\mathrm{S}_{\mathrm{m}}+\mathrm{N}_{\mathrm{n}}+\mathrm{B}_{\mathrm{jp}}+\mathrm{E}_{\mathrm{ijklmnpq}}
$$

with $\mathrm{D}_{\mathrm{i}}$ : date of measurement (43 levels); $\mathrm{L}_{\mathrm{j}}$ : selected line (2 levels: High Line and Low Line); $\mathrm{T}_{\mathrm{k}}$ : milking occasion (2 levels: evening or morning milking); $\mathrm{P}_{1}$ : parity (5 levels: 1 st to 4 th lactation, 5th lactation and more); $\mathrm{S}_{\mathrm{m}}$ : stage of lactation (5 levels: less than 60 days, between 60 and 90 days, between 90 and 120 days, between 120 and 150 days, more than 150 days); $\mathrm{N}_{\mathrm{n}}$ : number of suckling lambs (2 levels: one suckling lamb, two or more suckling lambs); 
$\mathrm{B}_{\mathrm{jp}}$ : random effect of the ewe $\mathrm{p}$ within the line $\mathrm{j}$; $\mathrm{E}_{\mathrm{ijklmnpq}}$ : residual random effect.

The distributions of random components (ewe within line and residual) were assumed normal and the levels of random components were assumed independent.

\subsubsection{Estimation of genetic parameters}

Estimated genetic parameters were heritabilities and genetic correlations among seven milking traits and milk yield. Two analyses were conducted on the morning records of first lactation ewes; this group of ewes is indeed supposed to be unbiased since they are in first lactation and have not previously been culled for poor milking traits. The first analysis allowed the estimation of genetic parameters for data on an annual basis (data set $\mathrm{C}$ ). The second analysis was based on individual test-day records (data set B) using a multi-trait model in order to investigate heritabilities within lactation. The estimates of genetic parameters were computed with the ASReml software [10], in multi-trait analysis between different milk flow characteristics, according to an animal model including the following fixed effects:

$$
\mathrm{Y}_{\mathrm{ijklmnpq}}=\mathrm{A}_{\mathrm{i}}+\mathrm{L}_{\mathrm{j}}+\mathrm{C}_{\mathrm{k}}+\mathrm{M}_{1}+\mathrm{S}_{\mathrm{m}}+\mathrm{N}_{\mathrm{n}}+\mathrm{B}_{\mathrm{jp}}+\mathrm{E}_{\mathrm{ijklmnpq}}
$$

with $\mathrm{A}_{\mathrm{i}}$ : year (5 levels: 1997, 1998, 1999, 2000, 2001); $\mathrm{L}_{\mathrm{j}}$ : selected line (2 levels: Low Line and High Line); $\mathrm{C}_{\mathrm{k}}$ : cycle of lambing (2 levels: first or second cycle of lambing); $\mathrm{M}_{1}$ : age of the ewe at lambing (4 levels: less than 405 days, between 405 and 407 days, between 408 and 410 days, more than 410 days); $\mathrm{S}_{\mathrm{m}}$ : time between lambing and the first test-day record (4 levels: less than 41 days, between 41 and 43 days, between 44 and 45 days, more than 45 days); $\mathrm{N}_{\mathrm{n}}$ : number of suckling lambs (2 levels: one suckling lamb, two or more suckling lambs); $B_{j p}$ : random additive genetic effect of the ewe $p$ within line $j$; $\mathrm{E}_{\mathrm{ijklmnpq}}$ : random residual effect.

\section{RESULTS}

\subsection{Elementary statistics}

Milk production at milking (YT) was $829 \mathrm{~mL}$ and latency time (TL) lasted 29 s (Tab. II). Thus, as explained in Section 2.2, strict latency time should be about $14 \mathrm{~s}$. This result was in agreement with the strict TL estimation of 15 s on 50 Lacaune ewes by Marnet et al. [18]. TL measurements also have 
Table II. Means of milking traits.

\begin{tabular}{|c|c|c|c|c|c|c|}
\hline Traits & Unit & Mean & Minimum & Maximum & $\begin{array}{l}\text { Standard } \\
\text { deviation }\end{array}$ & $\begin{array}{l}\text { Coefficient } \\
\text { of variation }\end{array}$ \\
\hline Milk yield & $\mathrm{mL}$ & 829 & 100 & 2880 & 481 & $58 \%$ \\
\hline Latency time* & s & 29 & 1 & 296 & 22 & $75 \%$ \\
\hline $\begin{array}{l}\text { Time at maximum } \\
\text { milk flow }\end{array}$ & $\mathrm{s}$ & 30 & 10 & 110 & 23 & $78 \%$ \\
\hline $\begin{array}{l}\text { Maximum milk } \\
\text { flow }\end{array}$ & $\mathrm{mL} \cdot \mathrm{s}^{-1}$ & 12.9 & 1.0 & 73.0 & 6.2 & $48 \%$ \\
\hline Average flow & $\mathrm{mL} \cdot \mathrm{s}^{-1}$ & 5.4 & 0.1 & 24.7 & 3.7 & $69 \%$ \\
\hline $\begin{array}{l}\text { Phase of increasing } \\
\text { flow }\end{array}$ & $\mathrm{s}$ & 17.9 & 0 & 100 & 23.6 & $132 \%$ \\
\hline Phase of high flow & $\mathrm{s}$ & 16.9 & 10 & 100 & 11.8 & $70 \%$ \\
\hline $\begin{array}{l}\text { Phase of } \\
\text { decreasing flow }\end{array}$ & $\mathrm{s}$ & 14.9 & 0 & 100 & 18.2 & $122 \%$ \\
\hline
\end{tabular}

* Lack of 2500 records on TL due to the automatic jar used before March 1997.

been reported in the Sarda breed (15 s [16]) and in dairy goats (45 s [12]), using the INRA automatic milk recording devices. Other studies on milking traits in cattle, goats and sheep, never referred to TL as a specific milking trait $[6-8,14,19,22]$, but they are focused on time to reach the maximum flow.

The maximum milk flow (FM), on average $12.9 \mathrm{~mL} \cdot \mathrm{s}^{-1}$, was reached at $30 \mathrm{~s}$ after the latency time, or $59 \mathrm{~s}$ after the connection of the cluster (Tab. II). For other breeds, Labussière and Bruckmaier et al. obtained peak values about $10.0 \mathrm{~mL} \cdot \mathrm{s}^{-1}$ for PreAlpe ewes [14] and for Ostfriesian ewes [6], respectively. In other species, FM values were higher than our estimation and very variable: from $30 \mathrm{~mL} \cdot \mathrm{s}^{-1}$ to $58 \mathrm{~mL} \cdot \mathrm{s}^{-1}$ in cows $[7,8,15,19,22]$, and from $15.2 \mathrm{~mL} \cdot \mathrm{s}^{-1}$ to $25.9 \mathrm{~mL} \cdot \mathrm{s}^{-1}$ in dairy goats $[5,11]$.

However, a comparison of FM values is difficult since it depends on the lag time between successive measurements of milk yield. Under our experimental conditions, the value of FM was about $40 \%$ higher when the lag time was reduced by a half $\left(10.3 \mathrm{~mL} \cdot \mathrm{s}^{-1}\right.$ with a lag of $5 \mathrm{~s}$ versus $7.3 \mathrm{~mL} \cdot \mathrm{s}^{-1}$ with a lag of $10 \mathrm{~s}$; results obtained during the checking period of the automatic jars).

The average of the 11 calculated flows (FA) of an animal had a rate of $5.4 \mathrm{~mL} \cdot \mathrm{s}^{-1}$ (Tab. II). The schematic representation of the milk flow pattern can thus be decomposed into four phases (Fig. 1): an average latency time of $29 \mathrm{~s}$ followed by a strong increase of milk flow for $18 \mathrm{~s}$ leading to a maximum milk flow lasting for $17 \mathrm{~s}$ and finally a phase of decreasing milk flow of $15 \mathrm{~s}$. The observed milk flow patterns did not reveal "typical profiles" such as the "two peaks" of milk ejection reported by Labussière et al. [13]. The high milk level 
of our ewes could explain their flow patterns with a plateau of high milk flow. In fact, these females also have a high proportion of cisternal milk compared with alveolar milk, and no restrictive oxytocin levels (Marnet et al. [18]), essential for alveolar milk ejection. So, the first peak of milk emission is very long and the second peak of milk ejection crumpled up with the first one and may have masked the two peak milk flow profiles often described.

The coefficients of variation (Tab. II) were moderate to high: milk yield and maximum milk flow presented intermediate values $(50 \%)$, while average flow, latency time and the time at maximum milk flow had slightly higher coefficients of variations (75\%). The two phases of increasing and decreasing flows (TIF and TDF, respectively) had high coefficients of variation (125\%), reflecting a low precision of estimation of these variables.

\subsection{Effects of milk yield selection on milking ability}

\subsubsection{Factors of variation}

Almost all factors of variation (model 1) were significant for all studied traits. The exceptions were the following: a lack of effect of divergent lines on phase of increasing flow, milking occasion on latency time, and number of suckling lambs on latency time and phase of high flow. Least squares means of fixed effects are reported in Table III. For all milking traits, significant factors of variation (in a decreasing order of level of significance) were the stage of lactation, morning or evening milking, parity, divergent line and, finally, the number of suckling lambs. As a general trend, all effects positively affecting latency time had, an adverse effect on milk yield, maximum milk flow and the three flow phases.

The milking ability of females decreased with lactation stage and parity: average flow and maximum milk flow decreased markedly, phases of high flow and of decreasing flow decreased slightly, while latency time increased significantly (Tab. III). Bruckmaier et al. [5] and Ilahi [11] also showed evidence of a negative effect of lactation stage on milk emission in the goat, but Ilahi [11] observed the best milking ability at the second lactation of goats. The ewes who suckled two or more lambs had their subsequent milking ability improved (Tab. III). This is an original result for flow traits, not earlier reported for cows and goats which are usually studied without a suckling period. It is likely that the positive effect of the number of suckling lambs on milk yield has a beneficial impact on flow traits (up to $10 \%$ on FA). However, the number of lambs did not affect latency time. 
Table III. Analysis of variance of the milking traits: least squares means of the fixed effects.

\begin{tabular}{|c|c|c|c|c|c|c|c|c|c|}
\hline Traits & $\mathrm{N}$ & $\mathrm{YT}$ & $\mathrm{TL}$ & FM & FA & TFM & TIF & THF & TDF \\
\hline Unit & & $\mathrm{mL}$ & $S$ & $\mathrm{~mL} \cdot \mathrm{s}^{-1}$ & $\mathrm{~mL} \cdot \mathrm{s}^{-1}$ & $\mathrm{~s}$ & $\mathrm{~s}$ & $\mathrm{~s}$ & $\mathrm{~s}$ \\
\hline \multicolumn{10}{|l|}{ Selected lines } \\
\hline Low & 11617 & 684 & 27.7 & 11.0 & 4.2 & 23.0 & NS & 15.2 & 12.6 \\
\hline High & 22999 & 880 & 25.1 & 13.1 & 5.7 & 23.8 & & 17.3 & 15.6 \\
\hline Diff (\%) & & $+25 \%$ & $-10 \%$ & $+17 \%$ & $+30 \%$ & $+3 \%$ & & $+13 \%$ & $+21 \%$ \\
\hline \multicolumn{10}{|c|}{ Milking occasion } \\
\hline Morning & 17392 & 958 & NS & 13.5 & 6.3 & 25.0 & 18.8 & 18.4 & 18.1 \\
\hline Evening & 17224 & 606 & & 10.6 & 3.6 & 21.8 & 18.0 & 14.0 & 10.1 \\
\hline $\operatorname{Diff}(\%)$ & & $-45 \%$ & & $-24 \%$ & $-55 \%$ & $-14 \%$ & $-4 \%$ & $-27 \%$ & $-57 \%$ \\
\hline \multicolumn{10}{|l|}{ Parity } \\
\hline 1 & 9243 & 854 & 23.2 & 13.6 & 5.7 & 22.3 & 15.5 & 17.8 & 15.6 \\
\hline 2 & 9121 & 786 & 24.6 & 12.4 & 5.1 & 23.1 & 17.1 & 17.0 & 14.2 \\
\hline 3 & 6231 & 802 & 26.0 & 12.2 & 5.1 & 23.6 & 18.6 & 16.4 & 14.8 \\
\hline 4 & 4443 & 771 & 28.1 & 11.6 & 4.8 & 23.8 & 19.7 & 15.4 & 14.0 \\
\hline $5+$ & 5578 & 695 & 30.5 & 10.5 & 4.1 & 24.0 & 21.0 & 14.4 & 11.8 \\
\hline Diff $(\%)$ & & $-20 \%$ & $+27 \%$ & $-26 \%$ & $-33 \%$ & $+7 \%$ & $+30 \%$ & $-21 \%$ & $-28 \%$ \\
\hline \multicolumn{10}{|c|}{ Stage of lactation } \\
\hline 1 & 5553 & 971 & 24.9 & 13.9 & 6.3 & 26.5 & 20.7 & 19.0 & 16.9 \\
\hline 2 & 8844 & 894 & 24.7 & 13.5 & 5.8 & 24.7 & 18.8 & 17.7 & 16.3 \\
\hline 3 & 4799 & 771 & 25.8 & 12.3 & 4.9 & 21.8 & 16.0 & 16.0 & 14.8 \\
\hline 4 & 9111 & 666 & 27.0 & 10.7 & 4.1 & 21.5 & 17.0 & 14.5 & 12.2 \\
\hline 5 & 5868 & 608 & 29.7 & 9.8 & 3.7 & 22.7 & 19.4 & 14.0 & 10.3 \\
\hline $\operatorname{Diff}(\%)$ & & $-46 \%$ & $+18 \%$ & $-35 \%$ & $-52 \%$ & $-21 \%$ & $-26 \%$ & $-30 \%$ & $-49 \%$ \\
\hline \multicolumn{10}{|l|}{ Suckling lambs } \\
\hline 1 & 19658 & 748 & NS & 11.9 & 4.7 & 22.7 & 17.5 & NS & 13.4 \\
\hline 2 & 14958 & 815 & & 12.2 & 5.2 & 24.1 & 19.3 & & 14.8 \\
\hline Diff $(\%)$ & & $+9 \%$ & & $+2 \%$ & $+10 \%$ & $+6 \%$ & $+10 \%$ & & $+10 \%$ \\
\hline
\end{tabular}

NS: non significant.

YT: milk yield; TL: latency time; FM: maximum milk flow; FA: average flow; TFM: time at maximum milk flow; TIF: phase of increasing flow; THF: phase of high flow; TDF: phase of decreasing flow.

As expected, the difference between divergent lines for milk yield was about 25\% $(P<0.001)$ of the general mean (Tab. III). The High divergent line exhibited a smaller latency time than the Low line $(-10 \%)$, which suggests that selection on yield had a beneficial impact on latency time. As a general trend, traits representing milk flow (FM and FA) were positively affected by selection for high milk solid yield $(+17 \%$ and $+30 \%$ for maximum milk flow and average flow, respectively). Milking ease would be improved if maximum milk 
flow has a longer duration: this happens when ewes were primiparous and belonged to the High selected line $(+13 \%$ for phase of high flow and $+21 \%$ for phase of decreasing flow). As a main conclusion, the divergent selection practiced at La Fage, led to indirect improvement of milking traits.

\subsubsection{Phenotypic correlations}

As a whole, milking traits were globally highly correlated with yield at milking (Tab. IV): milk yield was associated with average flow $(+0.99)$, maximum milk flow $(+0.86)$, the phase of high flows $(+0.93)$ and the phase of decreasing flows $(+0.83)$, but it was less related to latency time and time at maximum milk flow ( -0.42 and +0.35 , respectively). Physically, a high milk quantity in the udder increased the level of intra-mammary pressure and led to high milk flow characteristics.

Table IV. Correlations within milking traits corrected by the fixed effects.

\begin{tabular}{lccccccc}
\hline Traits & YT & $\log ($ TL+4) & $\log ($ TFM $)$ & FM & FA & TIF & THF \\
\hline YT & & & & & & & \\
$\log ($ TL+4) & -0.42 & & & & & & \\
$\log ($ TFM $)$ & +0.35 & +0.51 & & & & & \\
FM & +0.86 & -0.76 & -0.05 & & & & \\
FA & +0.99 & -0.42 & +0.33 & +0.86 & & & \\
TIF & -0.13 & +0.71 & +0.83 & -0.46 & -0.17 & & \\
THF & +0.93 & -0.43 & +0.26 & +0.82 & +0.95 & -0.26 & \\
TDF & +0.83 & -0.05 & +0.48 & +0.51 & +0.83 & +0.05 & +0.76 \\
\hline
\end{tabular}

YT: milk yield; TL: latency time; FM: maximum milk flow; FA: average flow; TFM: time at maximum milk flow; TIF: phase of increasing flow; THF: phase of high flow; TDF: phase of decreasing flow.

The phase of increasing flow, independent from milk yield $(-0.13)$, was positively correlated with latency time $(+0.71)$ and time at maximum milk flow $(+0.83)$. Besides, maximum milk flow was positively connected to average flow $(+0.86)$ and phase of high flow $(+0.82)$. Also, note that a long latency time (TL) was usually followed by a weak maximum milk flow $(-0.76)$; this result was partly due to the definition of TL used here, depending on the initial milk flow necessary to reach $0.16 \mathrm{~L}$ in the jar (see Sect. 2.2). However, with the same milk flow recording devices, Ilahi [11] demonstrated in the goat that maximum milk flow was correlated with an estimated TL and strict TL at -0.67 and -0.52 , respectively. These results suggest the existence of common 
biological mechanisms regulating both the true delay of milk emission and the maximum flow.

\subsection{Genetic parameters}

The study of the genetic relationships among milking traits was performed on first lactations at morning milking. Two approaches were developed: the analysis of annual traits (data $\mathrm{C}$ ), and the analyses of the elementary data at milking (data B) by considering successive milk recordings as different traits.

\subsubsection{Annual traits}

\subsubsection{Heritability}

The heritability of the milk yield average per year was 0.44 (Tab. V). This value was higher than the heritability estimated by Barillet et al. [2] on total lactations of primiparous ewes at La Fage (heritability of 0.35 ). The heritabilities were also high for milking traits, with standard errors ranging from 0.06 to 0.09 .

Table V. Heritabilities (and standard errors) [on diagonal], genetic correlations (and standard errors) [above the diagonal] among annual milking traits: multi-trait analysis of primiparous ewes $(N=751)$.

\begin{tabular}{|c|c|c|c|c|c|c|c|c|}
\hline \multicolumn{9}{|l|}{ Traits } \\
\hline \multirow[t]{2}{*}{$\mathrm{YT}$} & 0.44 & -0.22 & +0.34 & +0.46 & +1.00 & +0.34 & +0.87 & +0.24 \\
\hline & (0.09) & $(0.13)$ & $(0.14)$ & $(0.11)$ & $(0.01)$ & (0.15) & $(0.23)$ & $(0.22)$ \\
\hline \multirow[t]{2}{*}{$\log (\mathrm{TL}+4)$} & & 0.55 & +0.75 & -0.92 & -0.25 & +0.78 & -0.78 & +0.93 \\
\hline & & (0.08) & (0.08) & $(0.04)$ & $(0.15)$ & $(0.07)$ & $(0.27)$ & $(0.15)$ \\
\hline \multirow[t]{2}{*}{$\log (\mathrm{TFM})$} & & & 0.42 & -0.64 & +0.29 & +0.99 & -0.54 & +1.00 \\
\hline & & & $(0.08)$ & $(0.10)$ & $(0.16)$ & (0.02) & $(0.34)$ & (0.19) \\
\hline \multirow[t]{2}{*}{ FM } & & & & 0.54 & +0.53 & -0.66 & +0.79 & -0.86 \\
\hline & & & & $(0.08)$ & $(0.12)$ & (0.09) & $(0.25)$ & $(0.19)$ \\
\hline \multirow[t]{2}{*}{ FA } & & & & & 0.30 & +0.33 & +0.82 & +0.10 \\
\hline & & & & & $(0.08)$ & $(0.17)$ & $(0.25)$ & $(0.29)$ \\
\hline \multirow[t]{2}{*}{ TIF } & & & & & & 0.43 & -0.56 & +1.00 \\
\hline & & & & & & $(0.08)$ & $(0.33)$ & $(0.17)$ \\
\hline \multirow[t]{2}{*}{ THF } & & & & & & & 0.07 & +0.22 \\
\hline & & & & & & & $(0.06)$ & $(0.61)$ \\
\hline \multirow[t]{2}{*}{ TDF } & & & & & & & & 0.16 \\
\hline & & & & & & & & $(0.07)$ \\
\hline
\end{tabular}

YT: milk yield; TL: latency time; FM: maximum milk flow; FA: average flow; TFM: time at maximum milk flow; TIF: phase of increasing flow; THF: phase of high flow; TDF: phase of decreasing flow. 
The highest values corresponded to maximum milk flow and latency time (heritabilities of 0.54 and 0.55 , respectively). The phase of increasing flows, the time at maximum milk flow and the average flow had intermediate heritabilities $(0.43,0.42$ and 0.30 , respectively), whereas the heritability of the phase of decreasing flows and the phase of high flows was weak (0.16 and 0.07 , respectively). In dairy cattle, the heritability of maximum milk flow was slightly smaller than our estimate, with values varying from 0.21 to $0.48[7,8,19,22]$. High heritability estimates could be explained by two main reasons: firstly, we used annual average milking traits while other authors computed either elementary data with a test-day model $[7,8]$ or a single average between evening and morning data [22]. Secondly, we recorded data in a single flock, while they recorded milking traits in several herds.

Concerning the three phases of milk flow (TIF, THF and TDF), the heritabilities were in disagreement with the literature: heritability estimates for the phase of high flows in other studies were higher than ours [7,8,22]. Conversely, for the phase of decreasing flows, the literature estimates were mainly smaller than ours $[7,8]$.

\subsubsection{Genetic correlations}

The genetic correlations between milking traits and milk yield were consistent with the differences between divergent lines (Tab. V): in first lactation, the more important the genetic level for milk, the higher the average flow $(+1.00)$, the longer the phase of high flows $(+0.87)$, the higher the maximum milk flow $(+0.46)$, the later the time at maximum flow $(+0.34)$ and the shorter the latency time $(-0.22)$. The genetic correlations between milk yield and milking traits were consistent with dairy cattle estimates for maximum milk flow and phase of decreasing flow $[8,19,22]$. Nevertheless, genetic correlations between milk yield and duration of high flow seemed to be zero or weak in cattle $[8,22]$, while our estimation was high $(+0.87)$.

Maximum milk flow was negatively and very strongly correlated with latency time $(-0.92)$. To a lesser extent, maximum milk flow was negatively related to both phases of increasing and decreasing flows $(-0.66$ and -0.86 , respectively). Even though there was a marked genetic link between maximum milk flow and the phase of high flows $(+0.79)$, the relation between maximum flow and average flow was somewhat weaker $(+0.53)$ : the higher the maximum flow, the longer the phase of high flows, and the shorter the two phases of increasing and decreasing flows. Conversely, the latency time was correlated to the time at maximum milk flow $(+0.75)$, the phases of increasing 
and decreasing flows $(+0.78$ and +0.93$)$. Nevertheless, in cattle, maximum milk flow was negatively linked with both phases of decreasing flow and high flow $[8,22]$, meaning that a high maximum flow is associated with a short plateau of high flow. Globally, the lack of precision of the measurement of the three phases (with a lag of $10 \mathrm{~s}$ used here) may explain this discrepancy with the bovine literature where the measures were made every $3 \mathrm{~s}$ [7, 8, 22].

Our estimations on primiparous ewes show a symmetric but opposite behaviour of latency time and maximum milk flow. The average flow was more connected to the genetic level of milk production than to the other milking traits.

\subsubsection{Heritability of elementary test-day traits}

The heritabilities according to the milk recording number were variable. On the one hand, milk yield, average flow, and to a lesser extent latency time had increasing heritabilities with lactation stage. On the other hand, maximum milk flow exhibited slightly decreasing trends (Fig. 2a).
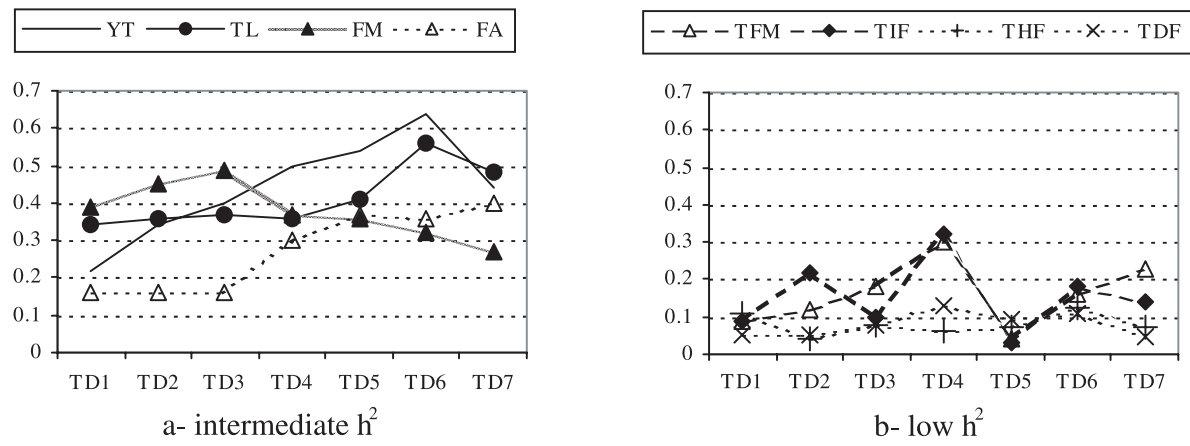

Figure 2. Heritabilities of milking traits according to the test-day record: multi-trait analysis for primiparous ewes $(N=751)$ (Standard errors from 0.07 to 0.10$)$.

The increase of the heritabilities of milk yield and average flow resulted from a strong reduction of the residual variance (results not shown) coupled with a moderate decrease of the genetic variance. However, the increase of the latency time heritability was due to an increase of the genetic variance, with the residual variance remaining stable. The decrease of the maximum flow heritability with lactation stage can be explained by a strong decrease of the genetic variance as compared to the residual variance. The heritabilities of time at maximum flow and phase of high flow do not show a clear trend along 
lactation stage, and the heritabilities of the phases of increasing and decreasing flow (TIF and TDF) remained stable but very low (Fig. 2b).

At the beginning of lactation and until the 5th test-day, maximum milk flow and latency time were the most heritable milking traits. As a general trend (milk yield apart), heritability estimates at each test-day were lower than the heritabilities of annual average milking traits. Also, our maximum milk flow heritability estimates, which vary between 0.29 and 0.50 , were more in accordance with the bovine estimates.

\section{DISCUSSION}

The results presented contribute to the evolution of dairy sheep selection programmes. Three main points should be stressed: (i) milking ability is a complex trait which should be correctly described for genetic purposes; (ii) the present criteria for dairy sheep selection are not antagonistic with milking traits; and (iii) the parameters calculated in this study can be used to improve genetic level on such new traits.

\subsection{Useful traits to determine milking ability in ewes}

In dairy sheep where milking is collective in large groups of ewes (about 48 animals milked simultaneously), milking time is a management characteristic rather than an animal's characteristic. Indeed, heritability of milking time is very low (ranging from 0 and 0.04 [9]), and cannot be integrated into a selection criterion. The average milk flow (ratio between milk yield and milking time) usually used to define the milking speed of an animal, also has a low heritability (from 0.11 to 0.19 [9]) and is poorly informative. Moreover, bovine appraisal of milking ease (a subjective score from 1 to 5 given by breeders $[4,21]$ ) is unusable in sheep, where the size of the flocks (about 400 ewes) keeps breeders from remembering the milking ability of each female.

Our automatic milk-recording device [20] allows a new descriptive approach of milking traits by identifying derived traits such as TL, FM, TFM, FA, TIF, THF and TDF. Amongst these criteria, latency time (TL) should be underlined. In fact, TL is an original trait, easier to record directly, and more accurately than flows. TL shows a high individual variability amongst animals, is highly genetically correlated with maximum milk flow, and is also the milking trait the less dependant on milk yield. Moreover, decreasing TL may provide an opportunity to reduce total milking time and milking labour costs. 


\subsection{Improvement of milking ability under current selection}

Our experimental design of divergent lines on milk yield clearly demonstrated that the current selection of dairy Lacaune ewes has an indirect favourable impact on milking ability. To our knowledge, this is the first report on the effects of experimental selection on milking traits. The attained divergence, a gap of 10 years of selection, involves a favourable response in milking ability by increasing maximum milk flow $(+17 \%)$, by lengthening the phase of high flows $(+13 \%)$, and by reducing the latency time $(-10 \%)$.

This indirect selection was due to the favourable genetic correlations between milk yield and milking traits reported in this study. These original results in ewes were in agreement with results in cattle where genetic correlations between milk yield and milking traits varied from 0.38 to 0.69 [8,19]. Anatomical and physiological studies on the ewes studied here, revealed that selection on milk solid yield might have also modified the internal teat conformation of ewes. The preliminary analysis of teat canal cross sections of 16 divergent line ewes show that the HL ewes had a canal diameter at the teat apex from 30 to $40 \%$ higher than the LL ewes (M. Manesse, personal communication). Moreover, the strength of the vacuum needed to extract the first milk drop was $10 \%$ weaker for the HL ewes than for the LL ewes. This indicates that the improvement of milking ability with current selection is partly due to a modification in the tone of the teat sphincter.

\subsection{Selection on milking traits is possible}

Among milking traits, latency time and maximum milk flow have higher heritabilities ( 0.55 and 0.54 , respectively): a selection on these traits would be feasible, if milk flow recording devices were available to breeders. The intermediate and stable heritability values of latency time (TL) and maximum milk flow throughout lactation (between 0.30 and 0.55 ) suggest that a single or few milk flow recordings per year and per ewe might be used for selection purposes. Moreover, we have previously demonstrated [17] that milking traits measured in first lactation and second lactation are genetically strongly correlated, with correlation values of 0.90 for latency time and 0.98 for maximum milk flow. So, selection based on primiparous ewes will have an impact on the later performance of ewes. However, latency time and maximum milk flow were strongly genetically connected $(-0.92)$ and thus genetically redundant. Since the genetic covariance between milk yield and maximum flow is about 55 times higher than the genetic covariance between milk yield and latency 
time (results not shown), the correlated response on milking ability with milk yield selection, assuming mass selection, would be higher on maximum milk flow than on latency time. It could, however, be interesting to improve milking ability, using a criterion combining TL and the present index based on solids in milk. Alternatively to directionally select on TL, further studies on selection on the variance of milking traits will be useful in order to evaluate the possibilities of canalising selection, aimed at the homogeneity of milking ability.

Nevertheless, before starting selection on milking ability, we need to verify if the increase of milk flow has an unfavourable impact on udder health. In dairy cattle, several studies indicate that milking ability is genetically and positively correlated with sub-clinical mastitis $[4,7,21]$. If such a link exists in dairy ewes, we almost need to perform selection on both "milking ability" and "udder health" traits.

\section{CONCLUSION}

As in dairy cattle, the dairy selection of Lacaune ewes shapes animals with phenotypically and genetically better milking traits. As a consequence of selection on milk yield, the latency time was shortened and the maximum milk flow was increased simultaneously to an increase of the phase of high flows. Thus, we are in an optimal situation in terms of the improvement of milking ability, without making direct measurements of these traits due to the favourable link with the current selection on milk yield. However, if the breeders wanted to, we could accelerate this improvement of the milking ability by direct selection. In this case, the objective of selection could be the reduction of the latency time until a minimum lag dependant on the milking installation, and thus the increase of the phase of milk emission with a higher maximum milk flow and a longer phase of high flows.

It is, however, necessary to verify the genetic impact of this milking ability increase on the shape of the udder, and on udder health, since indirect selection on milking traits seems to increase the diameter of the canal of the teat, which represents one of the barriers for the entrance of bacteria into the udder. According to these results, we can consider or not a joint selection on milk solid yield, somatic cell count and milking ability.

\section{ACKNOWLEDGEMENTS}

The authors sincerely thank all the colleagues of the INRA Domain of La Fage, the INRA-SAGA "dairy sheep team" for their collaboration in this work, as well as Mrs W. Brand-Williams for the language correction. 


\section{REFERENCES}

[1] Barillet F., Boichard D., Studies on dairy production of milked ewes. I. Estimates of genetic parameters for total milk composition and yield, Genet. Sel. Evol. 19 (1987) 459-474.

[2] Barillet F., Rupp R., Mignon-Grasteau S., Astruc J.M., Jacquin M., Genetic analysis for mastitis resistance and somatic cell score in French Lacaune dairy sheep, Genet. Sel. Evol. 33 (2001) 397-415.

[3] Barillet F., Genetics of milk production, in: Piper I., Ruvinsky A. (Eds.), The genetics of sheep, CAB International, 1997, pp. 539-564.

[4] Boettcher P.J., Dekkers J.C.M., Kolstad B.W., Development of an udder health index for sire selection based on somatic cell score, udder conformation, and milking speed, J. Dairy Sci. 81 (1998) 1157-1168.

[5] Bruckmaier R.M., Ritter C., Schams D., Blum W.B., Machine milking of dairy goats during lactation udder anatomy, milking characteristics and blood concentrations of oxytocin and prolactin, J. Dairy Res. 61 (1994) 457-466.

[6] Bruckmaier R.M., Paul G., Mayer H., Schams D., Machine milking of Ostfriesian and Lacaune dairy sheep: udder anatomy, milk ejection and milking characteristics, J. Dairy Res. 64 (1997) 163-172.

[7] Dodenhoff J., Sprengel D., Duda J., Dempfle L., Genetic correlations between somatic cell count and milkability traits, in: Proceedings International Workshop on Genetic Breeding Value Prediction for Functional Traits, 2000, Bull. No. 23 Int. Committee Anim. Recording, Wageningen, The Netherlands.

[8] Duda J., New prospects in sire evaluation for milkability, Proc. Int. Workshop Genet. Improvement of Functional Traits in Cattle, 1996, Bull. No. 12 Int. Committee Anim. Recording, Uppsala, Sweden.

[9] Flamant J.C., Estimation des paramètres génétiques du temps de traite, du débit moyen et des volumes de lait recueillis au cours des différentes phases de la traite des brebis, Ann. Zootech. hors-série (1974) 159-162.

[10] Gilmour A.R., Thompson R., Cullis B.R., Welham S.J., ASREML Manual. New South Wales, Department of Agriculture, Orange, 2800, Australia 2002.

[11] Ilahi H., Variabilité génétique du débit de traite chez les caprins laitiers, Ph.D. thesis, ENSAR/INRA, July 1999, 95 p.

[12] Ilahi H., Chastin P., Bouvier F., Arhainx J., Ricard E., Manfredi E., Milking characteristic of dairy goats, Small Rumin. Res. 34 (1999) 97-102.

[13] Labussière J., Martinet J., Denamur R., The influence of the milk ejection reflex on the flow rate during the milk of ewes, J. Dairy Res. 36 (1969) 191-201.

[14] Labussière J., Review of physiological and anatomical factors influencing the milking ability of ewes and the organization of milking, Livest. Prod. Sci. 18 (1988) 253-274.

[15] Le Du J., de La Chevalerie F.A., Taverna M., Dano Y., Aptitude des vaches à la traite mécanique : relations avec certaines caractéristiques physiques du trayon, Ann. Zootech. 43 (1994) 77-90.

[16] Marie-Etancelin C., Rupp R., Casu S., Carta A., Barillet F., New objectives of selection related to udder health, morphology and milkability in dairy sheep, 
52th Annual Meeting of the European Association for Animal Production, Budapest, Hungary, August 26-29, 2001, 4 p.

[17] Marie-Etancelin C., Arhainx J., Aurel M.R., Autran P., Bibé B., Jacquin M., Lagriffoul G., Pailler F., Porte D., Ricard E., Barillet F., Estimates of genetic parameters for milk flow kinetics during machine milking in French Lacaune dairy sheep, in: Proceedings of the 7th World Cong. Genet. Appl. to Livest. Prod., 19-23 August 2002, Montpellier, France, CD-ROM communication No. 01-51.

[18] Marnet P.G., Négrao J.A., Labussière J., Oxytocin release and milk ejection parameters during milking of dairy ewes in and out of natural season of lactation, Small Rumin. Res. 28 (1998) 183-191.

[19] Miller R.H., Pearson R.E., Weinland B.T., Fulton L.A., Genetic parameters of several measures of milk flow rate and milking time, J. Dairy Sci. 59 (1976) 957-964.

[20] Ricard E., Arhainx J., Guillouet P., Bouvier F., Jacquin M., Chastin P., Astruc J.M., Lagriffoul G., Manfredi E., Barillet F., On farm test of portable electronic jars for automatized milk recording of sheep and goats, in: Proceedings of the 29th session of ICAR, Ottawa 1994.

[21] Rupp R., Boichard D., Genetic parameters for clinical mastitis, somatic cell score, production, udder type traits, and milking ease in first lactation Holsteins, J. Dairy Sci. 82 (1999) 2198-2204.

[22] Santus E., Bagnatos A., Genetic parameters estimation for milkability traits recorded with flowmeters in Italian brown Swiss, in: Proceedings of the 6th World Cong. Genet. Appl. Livest. Prod., 11-16 January 1998, Vol. 25, University of New England, Armidale, pp. 19-22.

[23] SAS $^{\circledR} /$ STAT, Technical report P229, changes and enhancements, release 6.07, SAS $^{\circledR}$ Institut Inc., Cary, NC, USA, 1992.

To access this journal online: www.edpsciences.org 